\title{
Evaluation of cytotoxicity and antioxidant properties of some Zingiberaceae plants
}

\author{
Anish Nagi*, Manaswini Chakraborty², Ritesh Banerjee ${ }^{2}$, Anita Mukherjee ${ }^{2}$ \\ ${ }^{1}$ Department of Life Sciences, CHRIST (Deemed to be University), Bengaluru, Karnataka, India, \\ ${ }^{2}$ Department of Botany, Cell Biology and Genetic Toxicology Laboratory, University of Calcutta, Kolkata, \\ West Bengal, India
}

\begin{abstract}
Aim: Zingiberaceae family is widely distributed in the tropical realm of Asia. Considering its diverse applications as spices and therapeutics, the present study was undertaken to evaluate the cytotoxic and antioxidant effect of the ethanolic rhizome extracts of five plants, namely Alpinia galanga (L.) Willd., Alpinia zerumbet (Pers.) B.L. Burtt and R. M. Smith, Curcuma caesia Roxb., Zingiber officinale Rosc., and Zingiber zerumbet (L.) Smith on Allium cepa Linn. system. Materials and Methods: Cytotoxicity was evaluated by 2,3,5-triphenyltetrazolium chloride (TTC) and 2',7'-dichlorofluorescein diacetate $\left(\mathrm{DCFDAH}_{2}\right)$ assays. Further, in vitro DNA protection assay was performed to confirm the antioxidant potentials of the extracts. Characterization of phytochemicals was done by performing qualitative tests. Results and Discussion: TTC reduction assay revealed that the extracts $(2.5,5$, and $10 \mu \mathrm{g} / \mathrm{ml})$ had no cytotoxic effect on $A$. cepa root cells. Roots treated with extracts $(2.5 \mu \mathrm{g} / \mathrm{ml})$ were stained with reactive oxygen species-sensitive dye DCFDAH and visualized under the fluorescence microscope. The result confirmed that the extracts did not exert any prooxidant effect. Further, the extracts established their substantial antioxidant potential by inhibiting oxidative DNA damage in an in vitro system. In addition, qualitative analysis showed that the rhizomes are rich in phytochemicals. Conclusion: From the current observations, it can be concluded that the selected herbs can be utilized safely for human consumption.
\end{abstract}

Key words: 2,3,5-triphenyltetrazolium chloride, cytotoxicity, reactive oxygen species, Zingiberaceae

\section{INTRODUCTION}

$\mathrm{T}$ The plants belonging to the family Zingiberaceae, are widely distributed throughout the region of Southeast Asia $^{[1]}$ and are popularly used as spices and condiments in different ethnic cuisines. ${ }^{[2]}$ The aromatic rhizomes of some plants of this family, namely Alpinia galanga (AG), Alpinia zerumbet (AZ), Curcuma caesia (CC), Zingiber officinale (ZO), and Zingiber zerumbet (ZZ), are rich in complex mixture of diverse phytochemicals. They have a long history of traditional use in folk medicines in diverse ethnic groups and as ingredient in culinary preparations in Indian subcontinent. Literature survey on several epidemiological studies established a link between phytochemicals and the range of biological activities that impact health benefits in human beings. Scientific research supports the biological activity of many of the phytochemicals more in their native forms copiously used in Ayurveda and other traditional medicine, which dates back to Charaka Samhita ${ }^{[2,3]}$ Considering the growing trend of the usage of these natural products, it is imperative to carry evaluation of the safety of the rhizome extracts.

Among the higher plant species, Allium cepa has been recognized as excellent model to detect cytotoxicity and are frequently used in monitoring toxicity studies. A. cepa is used as a low-cost test. It is easily handled and has advantage over other short-term tests that require extensive preparation of test samples, as well as the addition of exogenous metabolic system. In addition, we have used A. cepa test to detect ROS generation.

Address for correspondence:

Anish Nag, Department of Life Sciences, CHRIST

(Deemed to be University), Bengaluru - 560029 ,

Karnataka, India.Phone: +91-7798134340.

E-mail: anish.nag@christuniversity.in

Received: $30-10-2018$

Revised: $13-12-2018$

Accepted: 19-12-2018 


\section{MATERIALS AND METHODS}

\section{Chemicals}

2, 3, 5-triphenyltetrazolium chloride (TTC) and 2', 7'-dichlorofluorescein diacetate $\left(\mathrm{DCFDAH}_{2}\right)$ were purchased from Sigma-Aldrich Inc. (CA, USA). Other chemicals were of analytical grade and purchased from Sisco Research Laboratory (SRL, Mumbai, India).

\section{Plant Materials}

(a) AG (L.) Willd., (b) AZ (Pers.) B.L. Burtt and R. M. Smith, (c) CC Roxb., (d) ZO Rosc., and (e) ZZ (L.) Smith are used.

Plant materials were collected from the medicinal garden of North Bengal University (NBU) and the botanical garden of Calicut University, Calicut. They were maintained in the experimental garden of the University of Calcutta, Kolkata. Dried voucher specimens were submitted to the NBU Herbarium with the accession numbers 09697 (AG), 09710 (AZ), 09709 (CC), 09702 (ZO), and 09716 (ZZ).

\section{Methods}

\section{Preparation of the rhizome extracts}

A total of $100 \mathrm{~g}$ of the dried rhizomes was soaked in $1 \mathrm{~L}$ of ethanol at room temperature $(35.5 \mathrm{C})$ and kept in the dark for 7 days. The ethanolic rhizome extracts of AG, AZ, CC, $\mathrm{ZO}$, and $\mathrm{ZZ}$ were filtered and evaporated to dryness by rotary evaporator ${ }^{[4]}$ and kept at $-20^{\circ} \mathrm{C}$ until further use. The extraction yields of $\mathrm{AG}, \mathrm{AZ}, \mathrm{CC}, \mathrm{ZO}$, and $\mathrm{ZZ}$ were 9.56, $7.08,6.99,7.0,3.44$, and $3.45 \%$, respectively.

\section{Phytochemical analysis}

Phytochemical analysis of the ethanolic extracts was carried out according to Barry, $1984^{[4]}$ and Ekwueme et al., 2015, ${ }^{[5]}$ with slight modifications. Following tests were performed.

\section{Test for alkaloids}

About $100 \mathrm{mg}$ of each of the extracts was added to $6 \mathrm{ml}$ of dilute hydrochloric acid and boiled. Solutions were filtered after cooling. Two drops of the Dragendorff's reagent were added to the filtrates and observed for the formation of a red precipitate.

\section{Test for flavonoids}

About $100 \mathrm{mg}$ of each of the extracts was boiled in ethyl acetate $(10 \mathrm{ml})$ for $3 \mathrm{~min}$, filtered, and cooled. Each of the filtrates $(4 \mathrm{ml})$ was shaken with $1 \mathrm{ml}$ of dilute ammonia solution, respectively, and observed for an intense yellow coloration.

\section{Test for terpenoids}

About $1 \mathrm{~g}$ of each of the extracts was added in $9 \mathrm{ml}$ of ethanol, refluxed for $5 \mathrm{~min}$, and filtered. The filtrate was concentrated and hot distilled water $(5 \mathrm{ml})$ was added. Then, the mixture was allowed to stand for an hour and the waxy mater was filtered off. The filtrate was extracted with $2.5 \mathrm{ml}$ of chloroform and was evaporated to dryness. Then, it was dissolved in concentrated sulfuric acid and heated for few minutes. The solutions were observed for gray color formation.

\section{Test for phenols}

Test sample (100 mg) was added to $1 \mathrm{ml}$ of distilled water. The solution was filtered, $5 \%$ ferric chloride solution was added and observed for deep blue color formation.

\section{Intracellular Ros Generation Potential and Cytotoxicity of the Rhizome Extracts}

\section{Visualization of the intracellular ROS}

Intracellular ROS generation in $A$. cepa (onion) roots was visualized under a fluorescence microscope (10X) using the fluorescent prob 2', 7'-dichlorofluoresceindihydrogendiacetate $\left(\mathrm{DCFH}_{2}-\mathrm{DA}\right)$. Rooted onion bulbs were incubated with the four plant extracts at a single concentration $(2.5 \mu \mathrm{g} / \mathrm{ml})$ for $24 \mathrm{~h}$. After incubation, roots were excised and washed with double distilled water. The excised roots were incubated with $25 \mu \mathrm{M} \mathrm{DCFH} \mathrm{H}_{2}-\mathrm{DA}$ in the dark for $30 \mathrm{~min}$ at $37^{\circ} \mathrm{C}$. Thereafter, roots were mounted on grease-free slides and visualized under fluorescence microscope $(\times 10)$ (BD Pathway, BD, San Jose, CA, USA).

\section{TTC reduction assay for cytotoxicity}

This study is aimed at showing TTC reduction in the assessment of cell survival following $24 \mathrm{~h}$ exposure of onion bulbs of different concentrations to extracts according to Towill and Mazur, 1975. ${ }^{[6]} 2-3$ roots $(2.0-3.0 \mathrm{~cm}$ root length) from each onion bulb of different concentrations of the extracts $(2.5,5$, and $10 \mu \mathrm{g} / \mathrm{ml})$ were dipped in $0.5 \%$ TTC solution for $10-15 \mathrm{~min}$ in dark at $37^{\circ} \mathrm{C}$. They were then dipped in $95 \%$ ethanol overnight at $-20^{\circ} \mathrm{C}$ to allow the stain to get extracted out into ethanol. The absorbance of the colored ethanol solution is recorded at $490 \mathrm{~nm}$. Results were expressed as the percentage (\%) of viability with respect to control according to the following formula:

$$
\left(\mathrm{R}_{\text {treated }} / \mathrm{R}_{\text {control }}\right) \times 100
$$

Where, $\mathrm{R}_{\text {treated }}=$ absorbance of the treated $A$. cepa roots and $\mathrm{R}_{\text {control }}=$ Absorbance of the control roots. All experiments were done in triplicate.

\section{Inhibition of oxidative DNA damage}

Inhibition of oxidative DNA damage by the four rhizome extracts was performed using supercoiled pBR322 plasmid DNA as an in vitro test system. Plasmid DNA was oxidized by $\mathrm{H}_{2} \mathrm{O}_{2} / \mathrm{Fe}^{2+} /$ ascorbic acid system. $0.5 \mu \mathrm{g}$ of DNA was added to Fenton's reagents $\left(30 \mu \mathrm{M} \mathrm{H}_{2} \mathrm{O}_{2}, 50 \mu \mathrm{M}\right.$ ascorbic 
acid, and $80 \mu \mathrm{M} \mathrm{FeCl}_{3}$ ) containing rhizome extract (2.5, 5 , and $10 \mu \mathrm{g} / \mathrm{ml})$. The final volume was made up to $12 \mu 1$. The mixture was then incubated for $30 \mathrm{~min}$ at $37^{\circ} \mathrm{C}$ and the DNA was resolved on a $1 \%$ agarose gel followed by ethidium bromide staining. Quercetin $(100 \mu \mathrm{M})$ was used as a reference standard. Densitometry analysis (band area) was done by ImageJ software (NIH, USA) and the histogram expressed using the formula:

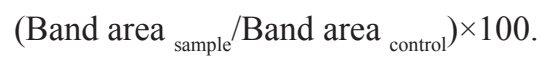

Where, Band area ${ }_{\text {control }}$ is the band area of the control DNA (without oxidizing system) and Band area ${ }_{\text {sample }}$ is the band area of nicked DNA in the presence or absence of antioxidant.

\section{Statistical Analysis}

All experiments were done in triplicate, and the data were expressed as means \pm standard deviation of three independent experiments. Data were analyzed using the Statistical Program - SigmaStat 3.0 (SPSS Inc., Chicago, IL, USA). One-way analysis of variance test, at $P \leq 0.05$, was done.

\section{RESULTS}

\section{Phytochemical Analysis}

The results of phytochemical analysis are shown in Table 1.

\section{Intracellular Reactive Oxygen Species (ROS) Generation Potential and Cytotoxicity of the Rhizome Extracts}

\section{Visualization of the intracellular ROS}

Formation of intracellular ROS in $A$. cepa (onion) roots was visualized by staining with $\mathrm{DCFH}_{2}-\mathrm{DA}$ and observed under fluorescence microscope $(\times 10)$. $\mathrm{DCFH}_{2}-\mathrm{DA}$ is enzymatically hydrolyzed by the intracellular esterases to form nonfluorescent $\mathrm{DCFH}_{2}$. This compound is further oxidized to highly fluorescent DCF by the intracellular ROS. DCF fluorescence intensity parallels the amount of intracellular ROS. Onion roots treated with extracts $(2.5 \mu \mathrm{g} / \mathrm{ml})$ did not show any increase in fluorescence when compared to control [Figure 1].

\section{Table 1: Qualitative analysis of the extracts}

\begin{tabular}{lcccc} 
Extracts & Alkaloid & Flavonoid & Terpenoid & Phenol \\
\hline $\mathrm{AG}$ & - & + & + & + \\
$\mathrm{AZ}$ & - & + & + & + \\
$\mathrm{CC}$ & - & + & + & + \\
$\mathrm{ZO}$ & - & + & + & + \\
$\mathrm{ZZ}$ & - & - & - & - \\
\hline
\end{tabular}

+: Present; -: Absent

\section{TTC reduction assay for cytotoxicity}

Reduction of TTC by tissue to the red-colored insoluble triphenylformazan (TF) is directly linked to the activity of the mitochondrial respiratory chain. Thus, only living tissues can reduce TTC to TF. The plant extracts did not affect the viability of $A$. серa root cells [Figure 2]. The positive compound ethyl methanesulfonate $(2 \mathrm{mM})$ was found to be cytotoxic causing $80 \%$ reduction of cell viability when compared to the control.

\section{Inhibition of oxidative DNA damage}

Plasmid DNA is normally represented as supercoiled DNA. Hydroxyl radicals generated by the $\mathrm{Fe}^{2+}+$ ascorbic acid $+\mathrm{H}_{2} \mathrm{O}_{2}$ caused significant oxidative breakage in the plasmid DNA strands to generate open circular or relaxed forms $(\sim 80 \%)$, as determined by agarose gel electrophoresis. The rhizome extracts $(2.5,5$, and $10 \mu \mathrm{g} / \mathrm{ml})$ showed significant reduction in the formation of open circular DNA with increased native supercoiled form of the plasmid DNA pBR322. AG, AZ, CC, and $\mathrm{ZO}$ restored native supercoiled form of the plasmid DNA significantly within the range of 24.96-35.24, 59.39-83.67, $43.87-89.65$, and $38.87-98.24 \%$ of the control, respectively [Figure 3]. Standard antioxidant quercetin $(100 \mu \mathrm{M})$ significantly inhibited the oxidative damage of the plasmid DNA ( 90\%).

\section{DISCUSSION}

Erratic incidences of several chronic diseases such as cancer, diabetes, cardiovascular, and neurodegenerative disorders entailed profuse pharmacological applications of antioxidantrich natural products. Antioxidants reduce ROS-mediated oxidative stress, a possible underlying principle behind their actions against chronic health issues. ${ }^{[7]}$

However, in the contrary, a report of Naik et al. ${ }^{[8]}$ indicated that the consumption of antioxidant-rich foods might increase the health risk $^{[9]}$ and showed the toxic effects of the ethanolic extracts of Alipinia galanga and C. longa in brine shrimp lethality bioassay with the $\mathrm{LD}_{50}$ values of 109 and $33 \mu \mathrm{g} / \mathrm{ml}$, respectively. Water extract of Distephanus angustifolius exhibited significant cytotoxic and genotoxic effects in the roots of A. cepa ${ }^{[10]}$ Alipinia galanga, Curcuma amada, and Zingiber officinale from the family Zingiberaceae are extensively used in culinary preparations as spices and condiments along with their medicinal importance. ${ }^{[2]}$

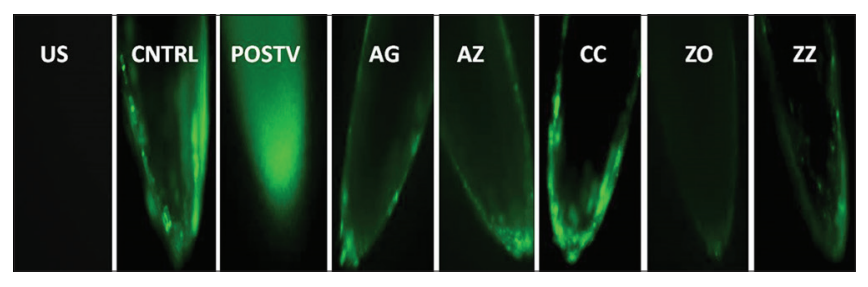

Figure 1: Fluorescence microscope images of Allium cepa roots exposed to plant extracts $(2.5 \mu \mathrm{g} / \mathrm{ml})$. US: Unstained, C: Control; P: Positive control - ethyl methanesulfonate (2 mM) 


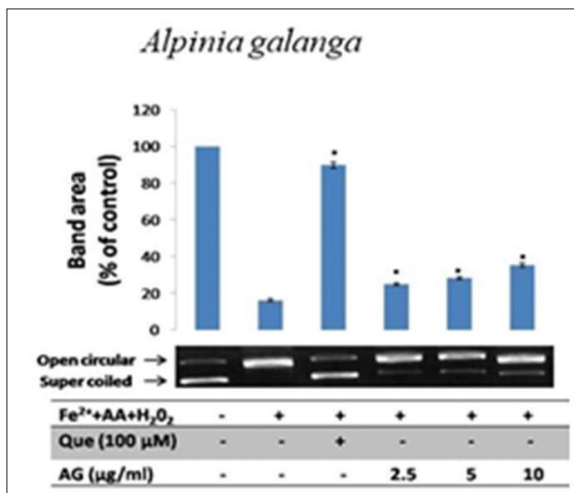

Curcumacaesia

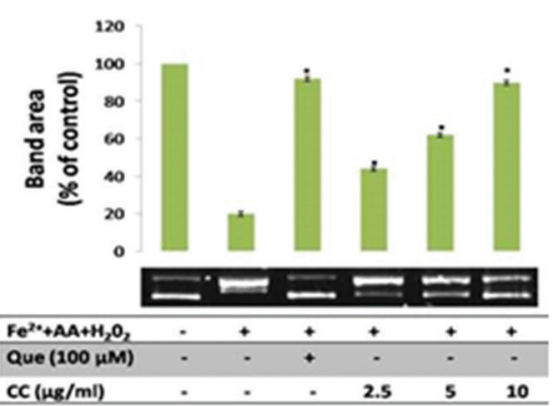

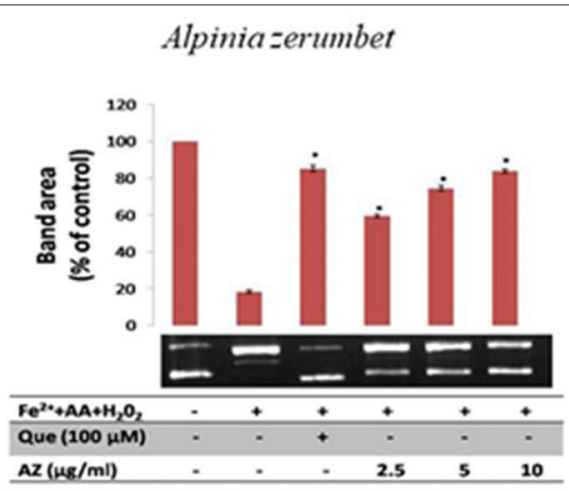

Zingiber officinale

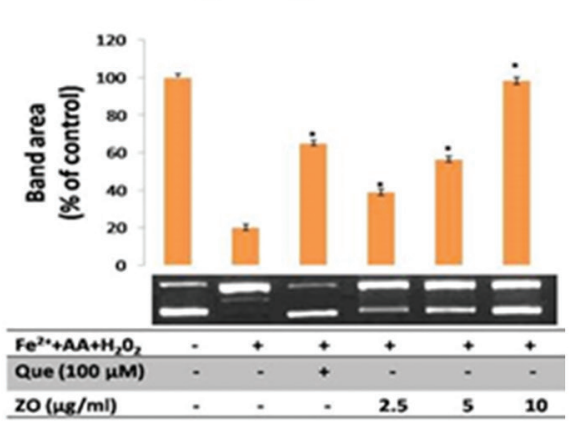

Zingiber zerumbet

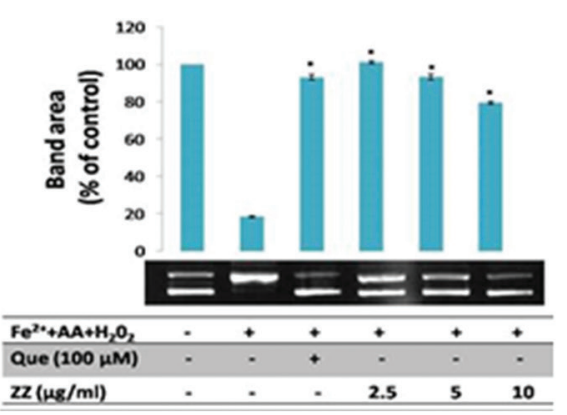

Figure 2: Protective effect of the extracts against $\mathrm{Fe}^{2+} /$ ascorbic acid/H2O2-induced oxidative DNA damage in plasmid DNA pBR322 visualized by agarose gel electrophoresis. Lane 1: Plasmid DNA pBR322 BSA incubated without $\mathrm{Fe}^{2+} / \mathrm{H}_{2} \mathrm{O}_{2} /$ ascorbic acid system system, Lane 2: Plasmid DNA pBR322 incubated with $\mathrm{Fe}^{2+} / \mathrm{H}_{2} \mathrm{O}_{2} /$ ascorbic acid system (positive control), Lane 3: Plasmid DNA pBR322 incubated with $\mathrm{Fe}^{2+}+\mathrm{H}_{2} \mathrm{O}_{2}$ /ascorbic acid system in the presence of reference standard quercetin $(100 \mu \mathrm{M})$, Lane 4, 5, and 6: Plasmid DNA pBR322 incubated with $\mathrm{Fe}^{2+} / \mathrm{H}_{2} \mathrm{O}_{2} /$ ascorbic acid system and 2.5, 5, and $10 \mu \mathrm{g} / \mathrm{ml} \mathrm{CA}$, respectively. Each value is expressed as the mean \pm standard deviation $(n=3)$. ${ }^{*}$ Statistically significant than the control $(P \leq 0.05)$

On the other hand, the rhizomes of $\mathrm{AZ},{ }^{[11]} \mathrm{CC},{ }^{[12]}$ and $\mathrm{ZZ}^{[1]}$ are reported to impart a wide range of pharmacological applications. Such frequent uses of these rhizomes demand in-depth research on their toxicological properties.

In the present study, it was evident that the rhizome extracts were rich in flavonoids and terpenoids. However, few reports on the cytotoxicity of these classes of compounds often complicated the universal safety issues of bioactive natural antioxidants. For example, the role of the flavonoid quercetin was questioned due to its exacerbated membrane damage in HL-60 cells in combination with the cytotoxic chemical menadione. ${ }^{[13]}$ Similarly, at high concentrations, sesquiterpenoid nerolidol elicited clastogenic effects in the mouse cells. ${ }^{[14]}$ Considering these findings, test concentrations $(2.5,5$, and $10 \mu \mathrm{g} / \mathrm{ml})$ of the rhizome extracts were subjected to the evaluation of cytotoxicity.

The mitochondrion is the powerhouse of a cell and plays a critical role through its bioenergetics function. ${ }^{[15]}$ Oxidative stress-induced mitochondrial dysfunction may contribute to several health hazards such as obesity, diabetes, neurodegenerative, and neuromuscular disorders. ${ }^{[16]}$ In this context, the effect of extracts on the mitochondrial activity of $A$. серa roots was assessed using TTC assay. TTC is a vital stain and the reduction process to formazan is active only in living cells due to the presence of active 


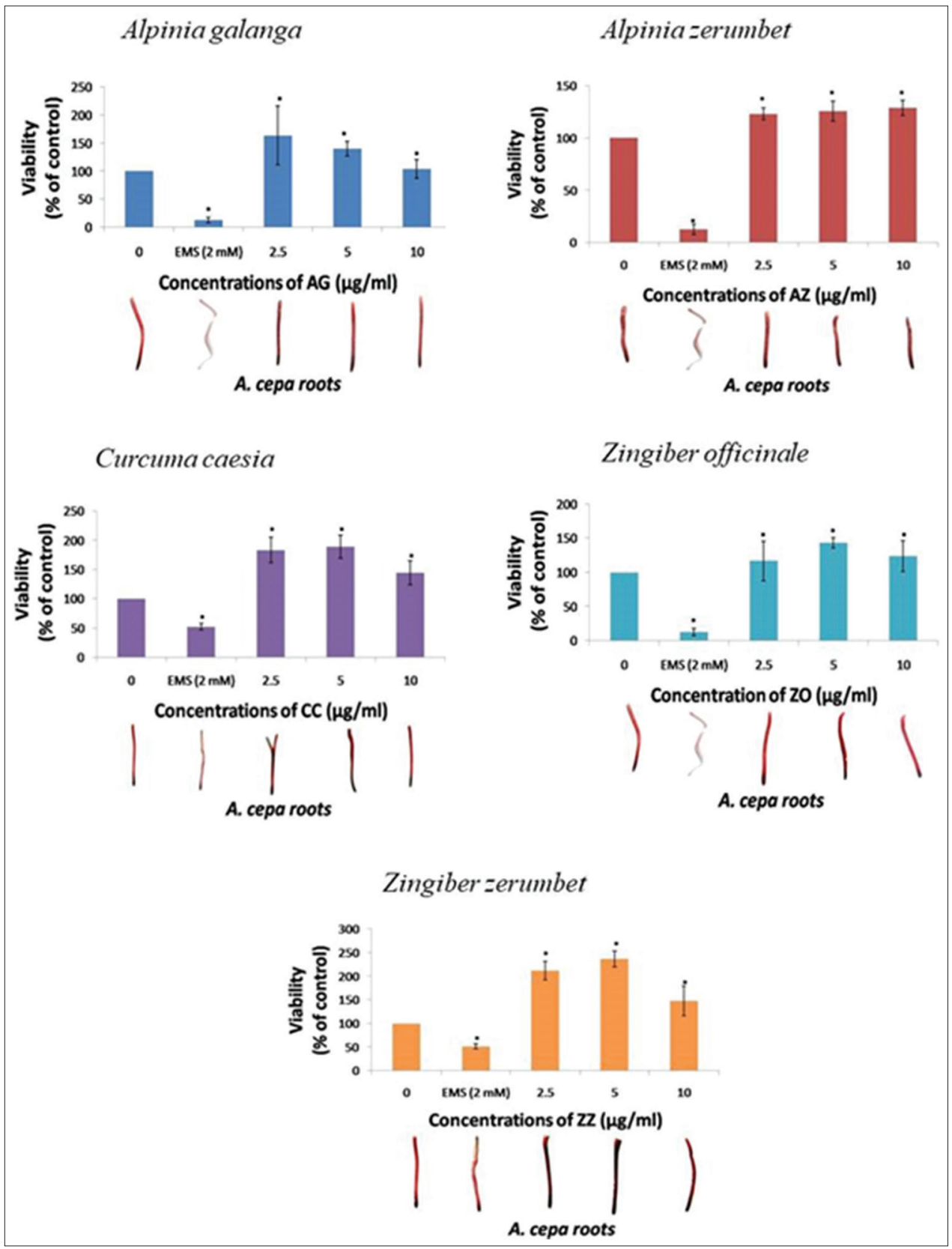

Figure 3: Cytotoxicity (2,3,5-triphenyltetrazolium chloride assay) of the plant extracts studied in Allium cepa root cells. *Statistically significant from control $(P \leq 0.05)$

mitochondrial enzymes. ${ }^{[6]}$ This dye accepts electron from mitochondrial respiratory chain and thus directly reflects the integrity of mitochondria. ${ }^{[17]} \mathrm{NADH}$ dehydrogenase and cytochrome $\mathrm{C}$ oxidase are the probable electron donors to TTC. ${ }^{[18]}$ Our data demonstrated that test concentrations $(2.5$, 5 , and $10 \mu \mathrm{g} / \mathrm{ml}$ ) of the extracts did not have any cytotoxic effects on the roots of $A$. cepa. This observation might be translated into the finding by Chang et al. ${ }^{[1]}$ where acute and 28-day subchronic oral treatments of the ethanolic extract of Zingiber zerumbet rhizome were found safe in the Wister rats. However, the increased cell viability of the treated onion roots in comparison with the control could be explained as the nutrient effect endowed by the rhizome extracts, rich in bioactive compounds. ${ }^{[19]}$
Oxidative stress fuels the damage of cellular metabolic activity. Mindful the complexity in the interaction of oxidative stress and metabolic activity, the $\mathrm{DCFDAH}_{2}$ staining technique was incorporated in this study. DCFDAH ${ }_{2}$ is an effective indicator of the physiological status of a cell by elucidating its intracellular ROS level. ${ }^{[13]}$ Antioxidants interfere with the conversion of non-fluorescent DCFDAH $\mathrm{H}_{2}$ to highly fluorescent DCF by scavenging the reactive species, whereas prooxidants propagate ROS production resulting in increased fluorescence, i.e., conversion to DCF. Various antioxidant molecules such as vitamin $\mathrm{C}, \alpha$-tocopherol, carotenoids, flavonoids, and phenols were reported to exert significant oxidative stress. ${ }^{[20]}$ Therefore, we envisaged the ability of the extracts $(2.5 \mu \mathrm{g} / \mathrm{ml})$ to generate ROS by visualizing the treated onion roots under 
the fluorescence microscope after staining with $\mathrm{DCFDAH}_{2}$. The result demonstrated that none of the extracts were capable of the production of ROS. When compared with the control, the partial decrease in the fluorescence of $A$. cepa roots treated with $\mathrm{ZO}$ and $\mathrm{ZZ}$ indicated that these extracts did exert an antioxidant effect directly or indirectly. Inhibition of oxidative DNA damage by the all five extracts induced by Fenton's reagent in the plasmid DNA system further confirm our claim. Interestingly, ZO was found to be the most powerful antioxidant. Potential antioxidant properties of the rhizome extracts of $\mathrm{ZO}^{[21]}$ and $\mathrm{ZZ}^{[22]}$ exhibited by various authors concurred with this assumption as well.

\section{CONCLUSION}

The present outcome of this work clearly indicated that the test concentrations of five ethanolic rhizome extracts did not show any cytotoxic effects in $A$. cepa roots and exerted strong antioxidant potentials.

\section{ACKNOWLEDGMENTS}

The authors would like to acknowledge DST, New Delhi, Innovation in Science Pursuit for Inspired Research (INSPIRE) for providing fund to Anish Nag.

\section{REFERENCES}

1. Chang CJ, Tzeng TF, Liou SS, Chang YS, Liu IM. Regulation of lipid disorders by ethanol extracts from Zingiber zerumbet in high-fat diet-induced rats. Food Chem 2012;132:460-7.

2. Sirirugsa P. Thai Zingiberaceae: Species diversity and their uses. World 1999;52:1-500.

3. Policegoudra RS, Aradhya SM, Singh L. Mango ginger (Curcuma amada Roxb.) a promising spice for phytochemicals and biological activities. J Biosci 2011;36:739-48.

4. Barry HJ. Phytochemical Methods. Vol. 278. London, New York: Chapman and Hall; 1984.

5. Ekwueme FN, Nwodo OF, Joshua PE, Nkwocha C, Eluka PE. Qualitative and quantitative phytochemical screening of the aqueous leaf extract of Senna mimosoides : Its effect in in vivo leukocyte mobilization induced by inflammatory stimulus. Int J Curr Micro Appil Sci 2015;4:1176-88.

6. Towill LE, Mazur P. Studies on the reduction of 2, 3, 5-triphenyltetrazolium chloride as a viability assay for plant tissue cultures. Can J Bot 1975;53:1097-102.

7. Bravo J, Arbillaga L, de Peña MP, Cid C. Antioxidant and genoprotective effects of spent coffee extracts in human cells. Food Chem Toxicol 2013;60:397-403.

8. Naik GH, Priyadarsini KI, Satav JG, Banavalikar MM, Sohoni DP, Biyani MK, et al. Comparative antioxidant activity of individual herbal components used in ayurvedic medicine. Phytochemistry 2003;63:97-104.

9. Khattak S, Saeed-ur-Rehman, Ullah Shah H, Ahmad W, Ahmad M. Biological effects of indigenous medicinal plants Curcuma longa and Alpinia galanga. Fitoterapia 2005;76:254-7.

10. Chukwujekwu J, Van Staden J. Cytotoxic and genotoxic effects of water extract of Distephanus anguli Folius on Allium cepa Linn. S Afr J Bot 2014;92:147-50.

11. Chompoo J, Upadhyay A, Kishimoto W, Makise T, Tawata S. Advanced glycation end products inhibitors from Alpinia zerumbet rhizomes. Food Chem 2011;129:709-15.

12. Karmakar I, Saha P, Sarkar N, Bhattacharya S, Haldar PK. Neuropharmacological assessment of Curcuma caesia rhizome in experimental animal models. Orient Pharm Exp Med 2011;11:251-5.

13. Bestwick CS, Milne L. Quercetin modifies reactive oxygen levels but exerts only partial protection against oxidative stress within HL-60 cells. Biochim Biophys Acta 2001;1528:49-59.

14. Pículo F, Guiraldeli Macedo C, de Andrade SF, Luis Maistro E. In vivo genotoxicity assessment of nerolidol. J Appl Toxicol 2011;31:633-9.

15. Kim YS, Hwang JW, Han YK, Kwon HJ, Hong H, $\mathrm{Kim} \mathrm{EH}$, et al. Antioxidant activity and protective effects of Trapa japonica pericarp extracts against tertbutylhydroperoxide-induced oxidative damage in chang cells. Food Chem Toxicol 2014;64:49-56.

16. Galati G, O'Brien PJ. Potential toxicity of flavonoids and other dietary phenolics: Significance for their chemopreventive and anticancer properties. Free Radic Biol Med 2004;37:287-303.

17. Ruf M, Brunner I. Vitality of tree fine roots: Reevaluation of the tetrazolium test. Tree Physiol 2003;23:257-63.

18. Rich PR, Mischis LA, Purton S, Wiskich JT. The sites of interaction of triphenyltetrazolium chloride with mitochondrial respiratory chains. FEMS Microbiol Lett 2001;202:181-7.

19. Fischer D, Li Y, Ahlemeyer B, Krieglstein J, Kissel T. In vitro cytotoxicity testing of polycations: Influence of polymer structure on cell viability and hemolysis. Biomaterials 2003;24:1121-31.

20. Sinha S, Jothiramajayam M, Ghosh M, Mukherjee A. Evaluation of toxicity of essential oils palmarosa, citronella, lemongrass and vetiver in human lymphocytes. Food Chem Toxicol 2014;68:71-7.

21. Stoilova I, Krastanov A, Stoyanova A, Denev P, Gargova S. Antioxidant activity of a ginger extract (Zingiber officinale). Food chem 2007;102:764-70.

22. Vaghasiya $\mathrm{BD}$, Nayak $\mathrm{Y}$, Jayashree B. In vitro antioxidant and antiglycation activity of Zingiber zerumbet (wild zinger) rhizome extract. Int J Res Pharm Sci 2013;4:482-9.

Source of Support: Nil. Conflict of Interest: None declared. 